\title{
CAPITAL MARKET INTEGRATION: PALESTINE AND ISRAELI EXPERIENCE
}

\author{
Tulus Suryanto \& Abdul Razak Abdul Hadi ${ }^{1}$
}

\begin{abstract}
Capital Market Integration: Palestine and Israeli Experience. This study is driven by the motivation to examine the existence of probable equilibrium and dynamic relations between Palestine Stock Exchange (PEX) and Tel Aviv Stock Exchange (TASE). Within the framework of international trade theories, this study uses Engle-Granger Co-integration procedure as an estimation model employing monthly time series data during the observed period from January 1998 till February 2012. It was discovered that there is a significant equilibrium relationship between PEX and TASE, but no empirical evidence was found on the presence of dynamic relations between the two stock markets using Granger Causality tests. Meanwhile, analysis of dynamic interactions over post-sample period by Impulse-Response Functions and Variance Decomposition indicate that movements in TASE Index do influence the performance of PEX.
\end{abstract}

Keywords: capital market integration, granger causality test, PEX, TASE

\begin{abstract}
Abstrak. Integrasi Pasar Modal: Pengalaman di Palestina dan Israel. Kajian ini didorong motivasi untuk menguji kemungkinan terjadinya keseimbangan dan hubungan dinamis antara bursa efek Palestina (PEX) dan bursa efek Tel Aviv (TASE). Dengan menggunakan kerangka teori perdagangan internasional, kajian ini menggunakan prosedur ko-integrasi Engle-Granger sebagai model estimasi atas data bulanan yang diobservasi mulai dari Januari 2008 sampai dengan Pebruari 2012. Hal yang ditemukan ialah terdapat hubungan keseimbangan yang signifikan antara PEX dan TASE, akan tetapi tidak ditemukan suatu bukti empiris atas hubungan dinamis antar dua bursa efek ini dengan uji kausalitas Granger. Sedangkan, analisis interaksi dinamis atas periode sampel yang ada dengan fungsi respon impuls dan dekomposisi variansi mengindikasikan bahwa pergerakan dari indek TASE berpengaruh terhadap kinerja PEX.
\end{abstract}

Kata Kunci: integrasi pasar modal, uji kausalitas granger, PEX, TASE

First draft: February, $3^{\text {rd }}$ 2015, Revision: Macrh, 5 ${ }^{\text {th }}$ 2015, Accepted: March, 30 2015

${ }^{1}$ IAIN Raden Intan Lampung. Jl. Letkol Endro Suratmin, Sukarame, Lampung -35131-

University of Kuala Lumpur. Jl. Sultan Islamil, Kuala Lumpur

Email : tulus_suryan70@yahoo.co.id; abdrazak@unikl.edu.my 


\section{Introduction}

Today, the Palestinian population is geographically divided and made up into four groups: 6 million Palestinians live outside Palestine, 3 million in West Bank, nearly 1.7 million in Gaza and 1.5 million in Israel itself. Free movement of commodities and trade relations are lacking among the four groups. Transfer of funds is restricted by the Israeli rules, and there is neither an airport nor a seaport in the state of Palestine. Today, the economy of Gaza heavily depends on Egypt especially after the Israeli siege in 2006. Since 1945, the international trade activities in Palestine has been reduced and controlled by Israel and only 29\% of Palestinian imports come from Egypt and Jordan. Meanwhile, 95\% of Palestine exports go to Israel and some 3\% find their ways to Egypt and Jordan. And the remaining 2\% goes to the rest of the world (Ministry of National Economy, 2005). Some informal sources stated that about $\$ 1.5$ billion value of trade between Gaza and Egypt in 2011 was done mainly through the underground tunnels.

Because of the limited investment opportunities in Palestine, most of the savings in the country are invested in foreign markets, especially in Egypt and Jordan. A recent study reveals that $75 \%$ of the six billion worth of deposits in the banks in Palestine are invested overseas and just 25\% are invested domestically (El-Eqtesadia, 2012). The high percentages of the savings are invested in neighboring countries, particularly in their stock markets. Common culture, history, language, religion and kinship facilitate personal interactions among the people. This demographic aspect reinforces the trade relations, tourism, labor mobility and investment flows.

It is a general belief that many equity investors prefer to invest in other countries rather than in their neighboring countries in order to enjoy an effective diversification effect. Yet this notion is opposed by Arshanapalli and Doukas (1993), Sheng and $\mathrm{Tu}$ (2000) and Izquierdo and Lafuente (2004). They postulate that the recent financial turmoil around the world was attributed to the mutual dependency of world financial markets. There are times when the effectiveness of cross-border diversification is advocated by fund managers. For this reason, regional portfolio investment among neighboring countries is still a credible strategy in maximizing portfolio returns. This study examines the capital markets integration involving Palestinian and Israeli stock markets with special attention given to the trend in portfolio investment.

This study was mainly meant to examine the directional relationship between PEX and TASE, and to determine the relative strength of the relationship between the two stock exchanges. This is inspired by the well-known phenomena that economic cooperation among neighboring countries could help sustain strong economic growth in the long run. This study attempts to provide useful insights to 
both local and foreign investors on the prospects of the two exchanges. This study deploys econometric time series analysis, Engle-Granger Co integration approach (1987), as an estimation model on the observed stock exchanges. Hadi, Yahya and Shaari (2009) employed the same approach in examining market integration involving fossil fuel markets. The following are the research questions that the study attempts to answer: first, is the performance of PEX affected by the movement in TASE index over time? Second, is there a causality effect that exists between PEX and TASE? Third, is there a theoretical support for TASE to be the leading indicator between the two stock exchanges?

\section{Literature Review}

Tel Aviv Stock Exchange (TASE) was founded in 1953 and owned by a consortium of 15 banks and 12 investment houses. At present, there are 622 companies listed in the exchange whose market capitalization valued at USD 216 billion. In 1993, TASE made a history by registering the third largest number of Initial Public Offerings (IPOs) of all the world stock exchanges. Headed by Esther Levanon, TASE was fully converted into computerized trading platform in 1999. Since 2007, there have been a number of international agreements formalized between TASE and other leading exchange around the world. Those are London Stock Exchange, NASDAQ and Canadian Stock Exchange to name a few. There are two main market indexes normally used as barometer to measure the performance of TASE. The two are TA-25 Index and TA-100 Index. The former is regarded as TASE's flagship index listing the top 25 largest companies by market capitalization (Barak, 2012).

The Egyptian stock market has strong influence over the establishment of Palestine stock exchange in late 1990s. Established in the late 1880s, the Egyptian exchange comprised of both Alexandria and Cairo stock exchanges. During the period from1888-1958, the stock exchange had been growing rapidly and at one point was ranked the fifth largest in the world (in terms of market capitalization) until the Egyptian government put some restrictions on its trading activities in 1959 (Mohie and Sourial, 2000). Like any other financial markets around the world, Egyptian stock exchange has gone through some reforms which led to the consolidation of both Alexandria and Cairo stock exchanges. In 2009, Egyptian Capital Market Authority was replaced by Egyptian Financial Supervisory Authority which assumes the functions as both regulatory and governing body. With better market mechanism, the Egyptian stock market had made its peak in 2009, registering transaction value of 91.2 billion Egyptian dollars (Hassan, 2009). In terms of informational efficiency, the Egyptian stock market is found to be in weak form 
(Hassan, Seyed and Mark, 2004). Another study by Daniel in 2005 on African stock markets also reveals consistent result.

PEX started its first trading session on 18 February 1997. In early February 2010, it was converted into a public shareholder company in conformity with good governance and transparency rules. According to the Arab and international classification of financial markets, the Palestinian exchange has attained advanced status in 2009. On 5 Nov 2012, a total of forty- eight companies were listed on the Palestinian exchange, with a market value of $\$ 2.7$ billion which was the highest compared to previous years. Palestinian listed companies operate in five major sectors - banking and financial services, insurance, investment, industry, and services. The PEX is an emerging capital market as most studies have indicated (Daraghma, 2010; Abu- Rub and Abu-Sharba, 2010). These studies describe the relationship between availability of information and its relationship with the share prices. Some indicate that PEX is efficient in weak form. The study of Zoa rob (2005) and Abu Sharbeh (2009) report that the lack of informational efficiency could be the reason for the volatility in the PEX.

Studies of the historical movement of the stock prices in the last 10 years show that unjustified fluctuations of stock prices are characterized by sharp movement in the indices' value that occurred during the period from 2005 through 2006 (Abdelkarim, 2007). From 2007 until today, high market volatility has been observed (Abu- Rub and Abu-Sharba, 2010). Market efficiency and poor governance are still issues of concern to both policy makers and investors. It is widely perceived that this phenomenon has been negatively affecting the fair pricing of stocks and consequently impair investors' confidence in the PEX as a whole.

Abdelkarim, Shahin, and Arqawi (2009), comment on the issue of stock market efficiency indicating that relevance and timeliness of financial and nonfinancial information are important for both pricing and market confidence, also it supports the investors in taking their decisions and judgments about the securities values; because of that and the desire to reach an efficient securities market, the regulators are increasingly concerned about the level of disclosure and availability of financial and non-financial information. Al-Quds Index (QI) is a market value weighted index and it was made up of 12 listed companies from different sectors in the Palestine exchange. This market index provides investors with a general idea about the direction and performance of the market. It is computed by dividing the total market value of all listed companies in the market for the current period over the total market value of companies included in the index for the previous period. This index has been used in PEX since the trading session in July 1997 where the closing prices in that session were used as a reference point in calculation. 


\section{Methods}

Vector Auto-Regressive Modeling (VAR) and Granger-Causality test are the main research tools in probing the equilibrium and short-run relations between the two stock exchanges - PEX and TASE. The co-movements of these two market indexes over time are presented. PEX is proxies by Al-Quds Index, while Tel Aviv Stock Exchange is represented by TA-100Index. The TA-100 Index is made up of 100 largest firms listed in TASE. The method used by Lance and James (2006) was applied to explore theoretical relations between the two market indexes. The stationary tests were first applied to the time series variables (via Augmented DickeyFuller Tests), then Engle-Granger Co integration modeling was used, and finally, Granger causality test (within sample) was employed for determining the existence of short-run relation between the tested variables.

Monthly observations were registered for the two market indexes, during the period from January 1998 till February 2012 involving 169 data points. EngleGranger Co integration test (1992) was applied to explore the statistical relation between the PEX and TASE. This statistical test was developed by Granger and Weiss (1981) and later re-formed by Granger (1986), Granger and Weiss (1983) and Engle and Granger (1987). Due to its dynamic functions, this statistical technique was met with wide acceptability among researchers who employed it in testing the validity of various theories and models. In fact co integration is essentially an econometric technique for testing the correlation between non-stationary time series variables. Two time series variables are considered to be co integrated when a linear combination of them is stationary, even though each one of them is nonstationary on its own.

First (or higher) differentiated data are necessary in tackling the problem of non-stationary among data series. But, one should be aware of the fact that using this differencing technique may result in a loss of precious data points on long-run characteristics of the time-series data. In fact when there is an equilibrium relationship between such variables, as Engle and Granger (1987) argue, the disequilibrium error should fluctuate about zero or equivalently the error terms should be stationary. Hence, unit root test is important to apply in determining the stationary of time series data. Any presence of unit root indicates a spurious regression relationship. This study uses the Augmented Dickey Fuller test in dealing with the unit root problem which is formulated as follows:

$$
\Delta \mathrm{Y}_{\mathrm{t}}=\lambda_{0}+\lambda_{1} \mathrm{~T}+\lambda_{2} \mathrm{Y}_{\mathrm{t}-1}+\Sigma \lambda_{\mathrm{i}} \Delta \mathrm{Y}_{\mathrm{t}-\mathrm{i}}+\varepsilon_{\mathrm{t}} \text { where } \mathrm{i}=1,2,3 \ldots \mathrm{k}
$$

The hypotheses to be tested are:

$\mathrm{H}_{0}: \lambda_{2}=0$ (the data is not stationary, it contains unit root)

$\mathrm{H}_{1}: \lambda_{2}<0$ (data is stationary, it does not contain unit root) 
Once the tested data series appear stationary at first difference (or higher), they are considered co integrated. Then, the Vector Error Correction Model (VECM) technique can be applied. This Model is a restricted Vector Autoregressive (VAR) technique. It is a unique technique that restricts the long run behavior of endogenous variables to converge to its co integrating relationship. In addition to that, it also allows for short run adjustments among the tested variables.

In investigating directional relationship between PEX and TASE, the study assumes only one causal direction: TASE affects PEX. Generally, a new stock exchange like PEX is always under the influence of a long established exchange like TASE. The case is even stronger when they are located so close to one another. The model adopted by this study is expressed as follows:

$$
P E X_{t}=\beta O+\beta 1 T A S E_{t}+\varepsilon_{t}
$$

where:

$$
\begin{aligned}
& \text { PEX = Palestine Stock Exchange (proxied by Al-Quds Index) } \\
& \text { TASE = Tel Aviv Stock Exchange Index } \\
& \varepsilon_{t}=\text { Error Terms }
\end{aligned}
$$

\section{Discussion}

In investigating the causal-effect relationship between PEX and TASE, statistical tests in time-series econometric modeling are applied involving Augmented Dickey-Fuller Unit Root Test (ADF) and Bi-variate Co integration Tests (ECM). Hypothesis testing is performed to determine the significance level of the unit root test. The result shows the P-values that indicate the level of significance. From the result, it is conclusive that both PEX and TASE are non-stationary at all lags, while the P-values from the result show that the first-differenced PEX and TASE data series are consistently stationary at all lags. The study also finds that both PEX and TASE are integrated at first difference. Hence, the preliminary requirements in Enger-Granger Co integration procedure have now been fulfilled.

Having the preliminary requirements met, the study performs long-run regression on the PEX and TASE data series (based on the model specification). The data shows the results of the regression analysis and rejection of the null hypothesis. This implies the presence of a statistically significant positive relationship between PEX and TASE. Meanwhile, the data provide the descriptive statistics and the correlation matrix of the two market indexes. It is evident that there exists a moderate degree of correlation between PEX and TASE. In order for OLS estimation to be statistically valid, Engle-Granger (1987) suggests that the long-run residuals derived from the long-run regression ( $r$ ) must be stationary. At this point, two important 
implications are highlighted: first, as the long-run residuals are proven stationary, the PEX and TASE are considered co integrated; second, having PEX and TASE cointegrated, the Vector Error Correction Model (VECM) can now be deployed for further analysis.

Table 1. Error Correction Model at Lag 2

\begin{tabular}{ccccc}
\hline \multicolumn{4}{c}{ Dependent Variable : dPEX } \\
Variables & Parameter & Standard Error & t-Value & P-Value \\
\hline Intercept & 2.1819 & 7.4844 & 0.29 & 0.7710 \\
LdPEX & 0.1808 & 0.0779 & 2.32 & 0.0215 \\
L2dPEX & -0.1458 & 0.0791 & -1.84 & 0.0674 \\
Lr & -0.1738 & 0.0486 & -3.57 & $0.0005^{*}$ \\
LdTASE & 0.0194 & 0.1802 & 0.11 & 0.9143 \\
LidTASE & -0.0680 & 0.1798 & -0.38 & 0.7057 \\
\hline Note: 1. dpex is first difference in PEX, Idpex is lag 1 of first difference in PEX
\end{tabular}

2. $\operatorname{lr}$ is lag 1 residual and ldTASE is lag 1 of first difference in TASE

By employing Bi-variate Error Correction technique, the coefficients of PEX and TASE variables in the model can now be estimated. The long term and short term responses involving the two tested variables are examined. It was found through Akaike results (AIC) that the optimum lag-length for the tested model lies at lag 2 (VECM technique prefers lower AIC value). The relevant results are summarized in Table 1.

The $l r$ is a lag 1 residual derived from VECM (2). This is the key component in VECM that supports long-term or equilibrium relationship between the two stock exchanges. A statistically significant equilibrium relation is observed by $l r$ 's p-value in Table 1. Given lr's parameter value of 0.1748 , this figure implies that there is approximately $17.48 \%$ speed of adjustment towards equilibrium made by PEX in the system. This adjustment is considered relatively fast and implies presence of market integration between the PEX and TASE. Theoretically, higher speed of adjustment is preferred because a statistically reliable endogenous variable should reflect high speed in its equilibrium adjustment.

A statistically significant positive relationship between the two exchange markets is applied by the positive parameter value of TASE $(+0.5095)$. This means that the two exchange markets are positively correlated. The existence of long-term significant relationship between the two exchanges could support the presence of a short-term relation between them. From the F-value, the alternative hypothesis is rejected suggesting non existence of a short-term relationship between the two neighboring stock exchanges. In ensuring that the OLS assumptions are put in check, diagnostic tests are carried out on the tested model. 
To examine constant variance of the error terms, LM ARCH test is applied. The test results are supports rejection of $\mathrm{H}_{0}$ at all levels. This clearly indicates that the residuals from the estimated model are homoscedastic or operating at constant variance. A normality test on error terms distribution should be applied before making any statistical inference. The test statistics explored by the study for normality depend on the distribution function involving Kolmogorov-Smirnov, Cramer-von Mises, and Anderson-Darling statistics. The results showing that the error terms from ECM (2) are not normally distributed for all four test statistics (see p-value). These findings do not detract from the whole picture, considering the study's preliminary nature. To ensure that all residuals are independent of one another, autocorrelation test is applied to examine any existence of serial correlation among the short-term residuals. Durbin-Watson test results support the absence of autocorrelation among the residuals

CUSUM analysis (or cumulative sum of residual test) is an important tool in econometric modeling. It is employed to tackle diagnostic problems related to parameter instability. From Figure 1 representing CUSUM analysis, existence of parameter (short-run and long-run parameters) stability is confirmed, the short-run residuals lying within the lower and upper boundaries. As a whole, the predictive model developed from this study can be considered credible since no major diagnostic shortcoming were met in the tested model.

Figure1. CUSUM Test (on Short-run Residuals of the Model)

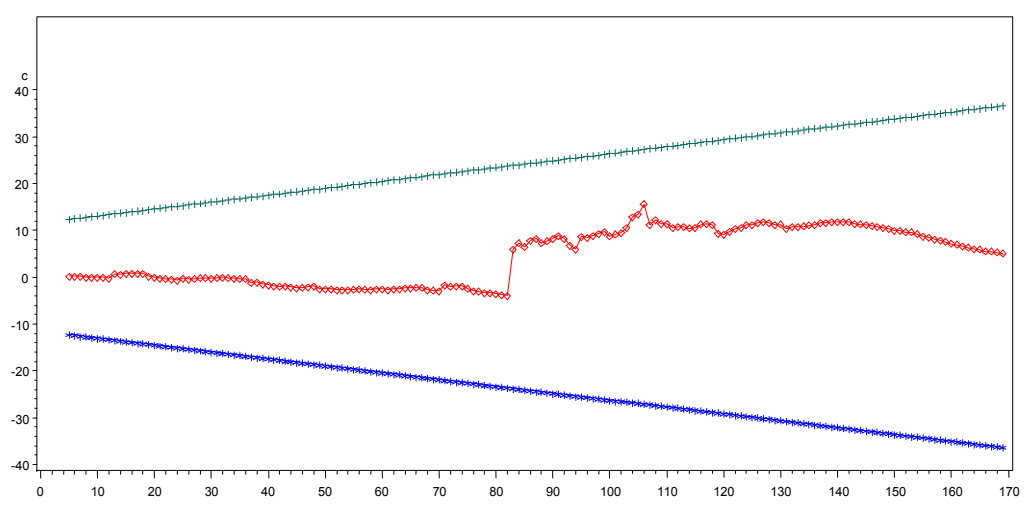

The results from diagnostic tests are free from major drawbacks and support the adoption of the suggested estimation model in the study. Interestingly, the empirical results are also consistent with earlier studies. In a nutshell, the evidence presented here confirms the intuition that performances of regional stock markets are mutually dependent. It is strongly recommended that future research should 
incorporate other regional markets such as Iraq and Syria. The study urges both Palestinian and Israeli governments to review their respective foreign policy and emphasize on beefing up bilateral trades among themselves. The fact that business globalization is inevitable, devising an effective and dynamic policy is of utmost importance in maintaining regional economic prosperity.

It is quite reasonable to argue the importance of an economic indicator such as stock market index in explaining the direction of an economic growth. Having understood the equilibrium relationship between PEX and TASE, policymakers should devise an effective approach in rejuvenating economic activities in the two countries. Similarly, stock traders and value investors should use this piece of information to come out with a trading strategy that can protect value of their investment portfolio. CUSUM analysis in depicted in Chart 1 also suggests the stability of both short-run and long-run parameters in the estimated model over the study period.

\section{Conclusion}

Despite the long hostility between Palestine and Israel, there is one thing that they share in common. The empirical findings from this study have proved that both PEX and TASE are co-integrated. Nevertheless, there is an absence of shortterm dynamic between the two markets indexes as revealed by Granger Causality test. Analysis of dynamic interactions over the post-sample period indicated that PEX is the most endogenous of all. Analysis of variance decomposition reveals $78 \%$ variations in PEX is explained by itself as compared to 92\% in TASE. From the analysis of impulse-response function, PEX is seen more responsive towards a given shock in TASE. These findings are very much in line with our model specification that performance of PEX is dependent upon the movements in TASE.

It is now evident that the neighboring countries like Egypt, Jordan and Israel play important roles in supporting the growth of Palestinian economy. TASE does influence the Palestinian economy through its capital market mechanism. The results obtained from this study clearly show the mutual benefits derived from international trade and portfolio investment involving the two neighboring countries. In particular, economic prosperity in Israel will undoubtedly help boost Palestinian economy as the two countries share national borders, resources and relatively same market structure. Hence, regional economic and political cooperation has to be improved between the two countries, which in turn help sustain long term economic growth. 


\section{References}

Abdelkarim, N \& Ijbara. 2010. Evidence on Corporate Governance Compliance by Palestine Securities Exchange Listed Firms. Global Journal of Business Research. Vol. 4, No. 3, pp. 73-88.

Abdelkarim, N. 2007. Evaluation the application's endeavors of listing and disclosure systems in Palestine Securities Exchange (In Arabic). Working paper, First Annual Palestinian Capital Market Forum, Ramallah (Sep.8-9), Palestine.

Abdelkarim, N. et.al. 2009. Investor Perception of Information Disclosed in Financial Reports of Palestine Securities Exchange Listed Companies. Accounting \& Taxation Vol. 1, No. 1, pp. 45-61.

Abusharbeh, T. 2009. Assessment of Financial Reporting and Disclosure Practices of Palestine Securities Exchange's listed companies in the light of Local Legal Requirements, International Accounting Standards and Investors Expectations (In Arabic). (Unpublished Dissertation). Jordan: Amman Arab University for Graduate Studies.

Arshanapalli, B. \& Doukas. 1993. International stock Market linkages: Evidence from the Pre-and Post-October 1987 Period. Journal of Banking \& Finance, 17, pp. 193-208.

Bekaert, G., et.al. 2005. Market integration and contagion. Journal of Business, 78(1), pp. 39-69.

Daraghma, Z. 2010. Board of Directors, Management Ownership, and Capital Structure and Its Effect on Performance: The Case of Palestine Securities Exchange. International journal of business and management Vol.5, No.11; November, pp. 119- 120.

Hassan, A., et.al. 2004. An Analysis of Day-of-the-Week Effects in the Egyptian Stock Market. International Journal of Business, 9(3), 2004, pp. 83-93.

Izquierdo, A.F. \& J.A. Lafuente. 2004. International transmission of stock exchange volatility: Empirical evidence from the Asian crisis. Global Finance Journal, 15, pp. 125-37.

Mohammad A. \& B. Salomon. 1996. Is MENA a Region?The Scope for Regional Integration. IMF working paper WP/96/30.

Sheng, H.C. \& A. Tu. 2000. A Study of Cointegration and Variance Decomposition Among National Equity Indices Before and During the Period of the Asian Financial Crisis. Journal of Multinational Financial Management, 10, pp. 345-365.

Zoa'rob, H. 2005. Testing the Operational effciency of The Palestine Securities Exchange. (In Arabic). Research Paper presented to the First Scientific Meeting held in The Islamic University (April, 0 -9), Gaza, Palestine. 